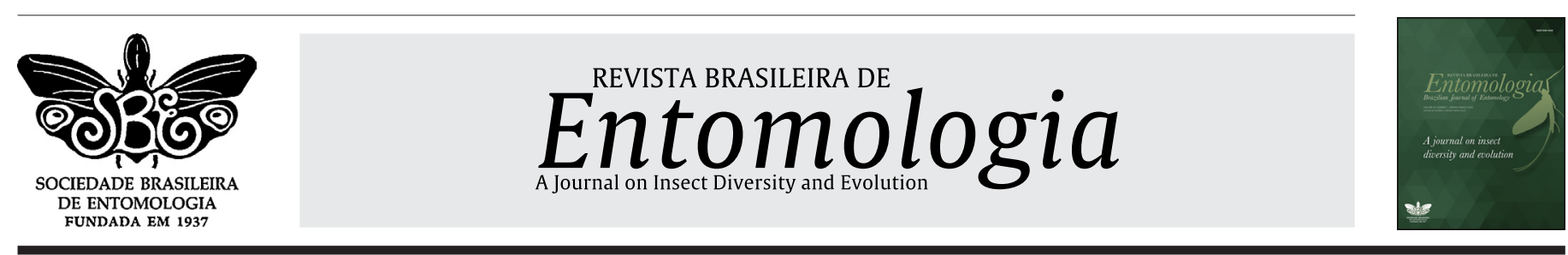

\title{
Potential interactions between herbivorous arthropods and of their natural enemies on Caryocar brasiliense (Caryocaraceae) trees
}

\author{
Germano Leão Demolin-Leite ${ }^{1}$ (D), Ronnie Von dos Santos Veloso ${ }^{2^{*}}$ (D), \\ Marcus Alvarenga Soares ${ }^{2}$ (D), Pedro Guilherme Lemes ${ }^{1}$ (i), \\ Geraldo Wilson Fernandes ${ }^{3}$ (D), José Cola Zanuncio ${ }^{4}$ (D) \\ ${ }^{1}$ Universidade Federal de Minas Gerais, Instituto de Ciências Agrárias, Montes Claros, MG, Brasil. \\ ${ }^{2}$ Universidade Federal dos Vales do Jequitinhonha e Mucuri, Departamento de Agronomia, Diamantina, MG, Brasil. \\ ${ }^{3}$ Universidade Federal de Minas Gerais, Departamento de Biologia Geral, Belo Horizonte, MG, Brasil. \\ ${ }^{4}$ Universidade Federal de Viçosa, Departamento de Entomologia/BIOAGRO, Viçosa, MG, Brasil.
}

\section{A R T I C L E I N F O}

\section{Article history:}

Received 09 February 2021

Accepted 14 May 2021

Available online 09 June 2021

Associate Editor: Gustavo Graciolli

\section{Keywords:}

Aphids

Eurytoma sp.

Pequi

Sycophila sp.

Zelus armillatus

\begin{abstract}
A B S T R A C T
The study of arthropod communities foraging on monocultures of native plants (e.g. Caryocar brasiliense) in biodiversity hotspots (e.g. Brazilian Cerrado) is important to understand the processes driving their performance. This study evaluated the possible interactions between galling herbivores, free-feeding arthropods, and of their natural enemies on $C$. brasiliense trees, in an orchard (monoculture). The possible competition observed were: i) between galling insects with defoliators and phytophagous mites, ii) between sucking insects, iii) between phytophagous mites and, iv) between Aphis gossypii (Hemiptera: Aphididae) with Histiostoma sp. (Acari: Histiostomidae) on C. brasiliense trees. Numbers of predators and prey, parasitoids and hosts, and predators and parasitoids were directly related among them. The competitive interactions between herbivorous predator and parasitoid may reduce Eurytoma sp. (Hymenoptera: Eurytomidae) populations, a potential pest of $C$. brasiliense. The predator Zelus armillatus (Hemiptera: Reduviidae) and the parasitoids Sycophila sp. (Hymenoptera: Eurytomidae) and Ablerus magistretti (Hymenoptera: Aphelinidae) are important to determine the numbers of Eurytoma sp. and of its galls. These natural enemies may be important to control this galling insect on $C$. brasiliense trees. The arthropod competition affected their guild associated to $C$. brasiliense trees.
\end{abstract}

\section{Introduction}

The high diversity and endemism of insects and plants characterize the Cerrado region as an important biodiversity hotspot (Bridgewater et al., 2004; Laste et al., 2019). The Cerrado biome occupies approximately $23 \%$ of the Brazilian territory with the second largest area after the Amazonian rainforest (Da Silva and Bates, 2002; Roitman et al., 2018). The phytophysiognomy of the Cerrado is structurally complex with a floristic composition from grasslands to forests areas with trees between 10-15 m high (Oliveira and Marquis, 2002). Planted forests, crops, and beef cattle occupy large areas of the Brazilian Cerrado (Sano et al., 2010).

Biodiversity reduction, deforestation and agricultural land use are major threats to Cerrado biodiversity (Symes et al., 2018). Extractivism, based on non-timber products, has low impact on this ecosystem (Schumann et al., 2010; Zardo and Henriques, 2011), but overharvesting products such as fruits and monocultures in large areas reduce plant regeneration and, consequently, the biodiversity (Leite et al., 2006a;

\footnotetext{
* Corresponding author.

E-mail: ronniesvelso@gmail.com (R.V.S. Veloso).
}

Giroldo and Scariot, 2015; Sanders et al., 2018). The environmental and economic relevance of the Cerrado is well known but its biodiversity functioning is not fully understood. The frequency with which new species are described indicates that many others remain undiscovered (Coelho et al., 2014; Souza and de-Paula Souza, 2016; São-Mateus et al., 2019; Colli et al., 2020). This increases the necessity of studies on inter and intra-specific relationships between organisms in the Cerrado biome.

Caryocar brasiliense Camb. (Caryocaraceae), an endemic tree widely distributed in the Brazilian Cerrado biome, particularly, in the Cerrado sensu stricto (Santos et al., 2015; Vieira Junior et al., 2020) presents high genetic diversity (Santos et al., 2018). The economic and social importance of this plant is high because many communities use its fruits for food and commercialization (Leite et al., 2006a, Zardo and Henriques, 2011). Legal protection aims to maintain C. brasiliense trees in the Cerrado biome (Leite et al., 2006a; Gonçalves et al., 2016), but individuals of this plant are left isolated in large extensions of monocultures, mainly in pastures. This isolation impacts the interspecific relationships between $C$. brasiliense and arthropod communities and the 
conversion of native forests into plantations affects the energy and mass flow between arthropods and plants (Barnes et al., 2014). Reduction of plant diversity due to agricultural monocultures can reduce inter- and intra-specific relationships, increasing the risks of biodiversity losses (Crutsinger et al., 2008; Koricheva and Hayes, 2018). The isolation of C. brasiliense in deforested areas of the Cerrado can negatively impact trophic interactions on this plant.

Environmental conditions and evolutionary parameters affect interactions between arthropod communities associated with tree species, such as $C$. brasiliense and, consequently, the identification of interactions and predicting anthropic actions in the ecosystem are often difficult. Inter-specific interaction studies are important for ecology research (Birkhofer et al., 2015; Tredennick et al., 2017) and, for this reason, a system composed of $C$. brasiliense and arthropods associated with this plant is a good study model due to this plant has a high richness and diversity of arthropods species (Leite, 2014). Herbivore damage to plants depends on their characteristics but that of gall insects and free-living sap-feeders may be similar (Zvereva et al., 2010). Galling insects are extremely abundant in all major ecosystems with many species damaging plant of economic importance (Espírito-Santo et al., 2007). The omnivorous and specialist predators negatively can affect herbivorous insects and their complementary functional traits contributes to pest control (Chailleux et al., 2017). Competition between predatory mites (Acari: Phytoseiidae) [e.g., Neoseiulus cucumeris (Oudemans) $\mathrm{x}$ Iphiseius degenerans (Berlese)], Tetranychus urticae (Koch) (Acari: Tetranychidae) females, hymenopteran galling insects [e.g., Eurytoma sp. (Eurytomidae) $\mathrm{x}$ other three galling insects], protocooperanting ants (Hymenoptera: Formicidae) [e.g., Tapinoma melanocephalum(Fabr.) x Paratrechina longicornis (Latreille)], and protocooperanting ants [e.g., Oecophylla smaragdina(Fabr.)] with song birds (Phylum Chordata, Class Aves, Subfamily Oscines) have been reported (Hammen et al., 2012; Macke et al., 2012; Leite et al., 2017; Liu et al., 2020; Supriya et al., 2020). The density of leaf chewer insects and mines was positively related to leaf damage, and arthropod groups responded to beech dominance and harvest intensity (Leite et al., 2012a).

The ecology of the arthropods interacting with $C$. brasiliense needs to be studied to protect this plant in nature and in plantations (monoculture). Predation, interference and competition are interspecific interactions affecting arthropod distribution (Ulyshen, 2011). Potential interactions (relative frequency, parasitism, predation and competition) were evaluated on C. brasiliense trees to test the hypothesis that interactions (cause and effect across of simple regression analysis) between defoliation herbivores (Coleoptera and Lepidoptera), sucking insects (Hemiptera), phytophagous mites (Acari) and galling insects (Hymenoptera) and of their natural enemies (parasitoids and predators, biological control) can affect negatively their populations (e.g., food competition or predation).

\section{Materials and methods}

\section{Study site}

The study was carried out in a 10 -year-old $C$. brasiliense monoculture (orchard) with $6,800 \mathrm{~m}^{2}$ and 272 plants, spaced $5 \times 5 \mathrm{~m}$ in the municipality of Montes Claros, Minas Gerais State, Brazil from June 2016 to June 2019. This area is located in the campus of the "Instituto de Ciências Agrárias da Universidade Federal de Minas Gerais (ICA/UFMG)” (16²0’54,5”S, $43^{\circ} 50$ '26,8"W with an altitude of 633 m elevation and dystrophic red oxisol with medium texture) with dry winters and rainy summers with Aw climate: tropical savanna according to Köppen (Alvares et al., 2013). These trees were $3.85 \pm 0.18 \mathrm{~m}$ high with $1.81 \pm 0.15 \mathrm{~m}$ crown width (average \pm standard error). The weeds between plant rows are controlled by monthly manual weeding.

\section{Study host plants}

Caryocar brasiliense Camb. (Caryocaraceae), with wide distribution in the Brazilian savanna (Cerrado) (Pinheiro and Monteiro, 2010; Santos et al., 2018), can reach over $10 \mathrm{~m}$ high and a $6 \mathrm{~m}$ wide canopy (Leite et al., 2006a). Its fruits are rich in oil, vitamins, proteins and compounds with medicinal importance, used for food, cosmetics, production of lubricants, in the pharmaceutical industry, and as the main source of income for many communities (Segall et al., 2005; Leite et al., 2006a; Khouri et al., 2007). Strategies for $C$. brasiliense conservation

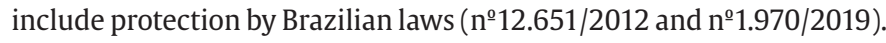
However, isolated individuals of this plant, left in deforested areas of the agro-landscape, are subjected to higher leaf, flower, and fruit damage by insects, representing a significant threat to $C$. brasiliense conservation (Leite et al., 2012a, 2012b, 2012c).

\section{Study design}

Fifteen plants, around $50 \mathrm{~m}$ apart from each other, were selected and marked among 272 C. brasiliense trees that made up the plantation. The characteristics of the plants selected were: i) healthy branches and trunks without damage by the fungus Phomopsis sp. and the wood borers Cossidae (Lepidoptera), respectively, since they cause high mortality of this plant (Leite et al., 2012d); ii) larger plants may host a greater number of arthropods (Leite et al., 2011; 2012a, 2016, 2017); and iii) evaluation of branches in the north, south, east and west sides of the apical, middle and basal parts of their canopies.

Arthropods were collected over three consecutive years (e.g., including rare ones), once a month, in the morning (7:00-11:00 A.M). The distribution of galling insects and of their galls, predators and parasitoids, insect defoliators, leaves with galls, sap-sucking Hemiptera and mites (Acari) was recorded on 12 fully expanded leaves (each leaf with three leaflets, all evaluated) from 15 C. brasiliense trees: four leaves from each stratum of the canopy (bottom, medium, and apical parts) and from each cardinal orientation of the branches (North, South, West, and East), totaling 6,480 leaves over 3 yr. were evaluated. Insect defoliation was evaluated visually by the leaf area losses on a $0-100 \%$ scale with $5 \%$ increments for the area removed (Silva et al., 2020) on the 15 trees ( 12 leaves/tree) per evaluation. Arthropods were observed during sampling and collected with tweezers, brushes, or aspirators and preserved in vials with $70 \%$ alcohol for identification by taxonomists.

Leaf samples were collected from $C$. brasiliense on multiple branches and transported to the laboratory, where the nymphs and adults (sum) of insects and mites (phytophagous and predators) were counted starting within $2 \mathrm{~h}$ after the material was collected by examining the leaves under a binocular microscope with $12.5 \mathrm{X}$ magnification (Leite et al., 2003). Three random areas were selected in the central part of each leaf blade (between the principal vein and the margin, adaxial and abaxial surface). Each area $\left(0.60 \mathrm{~mm}^{2}\right)$ was distributed per leaf part (distal, median, and proximal, near the petiole) (Leite et al., 2003). Mites on C. brasiliense were collected with a brush and preserved in in vials with $70 \%$ alcohol. The leaves were put in white plastic pots (temperature of $25^{\circ} \mathrm{C}$ ) and evaluated every two days to obtain the total number of galling insects, parasitoids, hyperparasitoids, and inquilines, during a 30 day data collection period. The insects were preserved as described and sent to taxonomists for identification. 
Statistical analyses

Mean number of each arthropod species per 12 leaves/tree/year were obtained, totaling 45 samples. The relative frequency, general (among all the arthropods) and specific (per group - e.g. sucking insects) means were calculated as $\mathrm{F}=(\mathrm{n} / \mathrm{N})^{*} 100$, where $\mathrm{n}=$ number of individuals for a taxon collected and $\mathrm{N}=$ total number of individuals collected. The relationship between the number of individuals (means, $n=45$ ) of each herbivorous arthropod and natural enemy species were subjected to simple regression analysis $(P<0.05)$ using the statistical program System for Analysis Statistics and Genetics (SAEG), version 9.1 (SAEG, 2007) (Supplier: "Universidade Federal de Viçosa"). Simple equations were selected by observing the criteria: i) distribution of data in the figures (linear or quadratic response), ii) the parameters used in these regressions were the most significant ones $(P<0.05)$, iii) $P<0.05$ and $F$ of the Analysis of Variance of these regressions, and iv) the coefficient of determination of these equations $\left(R^{2}\right)$.

\section{Results}

Relative frequency

The general relative frequency (80.5\%) of the galling wasp Eurytoma sp. (Hymenoptera: Eurytomidae) $(\mathrm{n}=15625)$ was the highest on $C$. brasiliense leaves (total arthropods $=19420$ ) (Table 1$)$. The Tetranychus sp.1 (Tetranychidae) (phytophagous mites) (69.6\%, $\mathrm{n}=102$ ), Aphis gossypii(Glover) (Hemiptera: Aphididae) (phytophagous Hemiptera) (77.7\%, n= 382), Eurytoma sp., a unique galling insect observed, Histiostoma sp. (Histiostomidae) $(\mathrm{n}=486)$, a unique detritivore arthropod observed, Sycophila sp. (Hymenoptera: Eurytomidae) (98.2\%, n= 2085), which is an Eurytoma sp. parasitoid, Quadrastichus sp. (Hymenoptera: Eulophidae) ( $\mathrm{n}=121)$, a unique Sycophila sp. parasitoid observed, Zelus armillatus (Lepeletier and Serville) (Hemiptera: Reduviidae) (predators) $(41.5 \%, n=176)$, galling insect (phytophagous arthropods) $(96.1 \%)$, and parasitoids (natural enemies) $(84.1 \%, \mathrm{n}=2245)$ were the arthropods with highest specific relative frequency inside their groups (Table 1).

Table 1

Total number of arthropods species ( $\mathrm{n}$ ) and of their groups (N), their specific (inside of each group -SRF) and general (among all the arthropods) relative frequency (\%) (GRF) on Caryocar brasiliense tree in three years. Montes Claros, Minas Gerais State, Brazil.

\begin{tabular}{|c|c|c|c|}
\hline Arthropods & & SRF & GRF \\
\hline \multirow[t]{4}{*}{ Phytophagous mites } & Acaridae $(n=25)$ & 16.89 & 0.13 \\
\hline & Eutetranychus sp. $(\mathrm{n}=7)$ & 4.66 & 0.04 \\
\hline & Tetranychus sp.1 $(\mathrm{n}=102)$ & 69.60 & 0.53 \\
\hline & Tetranychus sp.2 $(\mathrm{n}=13)$ & 8.84 & 0.07 \\
\hline \multirow[t]{2}{*}{ Phytophagous Hemiptera } & Aphis gossypii $(\mathrm{n}=382)$ & 77.67 & 1.96 \\
\hline & Pseudococcus sp. $(\mathrm{n}=110)$ & 22.33 & 0.56 \\
\hline Galling insects & Eurytoma sp. $(\mathrm{n}=15625)$ & 100 & 80.47 \\
\hline Detritivores & Histiostoma sp. $(\mathrm{n}=486)$ & 100 & 2.50 \\
\hline \multirow[t]{2}{*}{ Eurytoma sp. parasitoids } & Ablerus magistretti $(\mathrm{n}=39)$ & 1.82 & 0.20 \\
\hline & Sycophila sp. $(\mathrm{n}=2085)$ & 98.18 & 10.74 \\
\hline Sycophila sp. parasitoid & Quadrastichus sp. $(\mathrm{n}=121)$ & 100 & 0.62 \\
\hline \multirow[t]{5}{*}{ Predators } & Agistemus sp. $(\mathrm{n}=31)$ & 7.10 & 0.16 \\
\hline & Chrysoperla sp. $(\mathrm{n}=140)$ & 32.95 & 0.72 \\
\hline & Holopothrips sp. $(\mathrm{n}=24)$ & 5.68 & 0.12 \\
\hline & Spiders $(n=54)$ & 12.77 & 0.28 \\
\hline & Zelus armillatus $(\mathrm{n}=176)$ & 41.50 & 0.91 \\
\hline \multirow[t]{3}{*}{ Phytophagous } & Mites $(\mathrm{N}=147)$ & 0.90 & --- \\
\hline & Hemiptera $(\mathrm{N}=492)$ & 3.03 & --- \\
\hline & Galling insects $(\mathrm{N}=15625)$ & 96.07 & --- \\
\hline \multirow[t]{2}{*}{ Natural enemies } & Parasitoids ( $\mathrm{N}=2245)$ & 84.08 & --- \\
\hline & Predators $(\mathrm{N}=425)$ & 15.92 & --- \\
\hline
\end{tabular}

Competition between herbivores

The higher number of Eurytoma sp. adults, on C. brasiliense leaves, was negatively correlated with reduced defoliation $\left(\mathrm{R}^{2}=0.22, P<0.01\right)$ (Fig. 1 A) and numbers of Eutetranychus sp. (Tetranychidae) $\left(\mathrm{R}^{2}=0.25\right.$, $P<0.00)$ (Fig. $1 \mathrm{~B}$ ). The number of groups of Eurytoma sp. globoid galls $\left(\mathrm{R}^{2}=0.17, P<0.02\right)$ (Fig. $\left.1 \mathrm{C}\right)$ and the percentage of defoliation $\left(\mathrm{R}^{2}=0.20\right.$, $P<0.00$ ) (Fig. $1 \mathrm{D}$ ) were negatively correlated with that of Acaridae, and that of A. gossypii that of Pseudococcus sp. (Pseudococcidae) $\left(\mathrm{R}^{2}=0.18, P<0.02\right)$ (Fig. $\left.1 \mathrm{E}\right)$ and Histiostoma sp. (Histiostomidae) $\left(\mathrm{R}^{2}=0.12, P<0.03\right.$ ) (Fig. $1 \mathrm{~F}$ ). The numbers of Histiostoma sp. were negatively correlated with that of Eutetranychus sp. $\left(\mathrm{R}^{2}=0.20, P<0.01\right)$ (Fig. 2 A), Eurytoma sp. $\left(\mathrm{R}^{2}=0.14, P<0.04\right.$ ) (Fig. 2 B) and A. gossypii $\left(\mathrm{R}^{2}=0.12, P<0.03\right)$ (Fig. $2 \mathrm{C}$ ). Similarly, the numbers of Tetranychus sp.2 (Tetranychidae) $\left(\mathrm{R}^{2}=0.17, P<0.03\right)$ (Fig. $\left.2 \mathrm{D}\right)$ and Eurytoma sp. $\left(\mathrm{R}^{2}=0.31, P<0.00\right)$ (Fig. $2 \mathrm{E}$ ) were negatively correlated with that of Eutetranychus sp.. The higher number of Tetranychus sp.1 reduced the number of Eurytoma sp. globoid galls $\left(\mathrm{R}^{2}=0.20, P<0.01\right.$ ) (Fig. $2 \mathrm{~F}$ ). A similar relationship was observed between the numbers of Tetranychus sp.2 and Tetranychus sp. $1\left(\mathrm{R}^{2}=0.29, P<0.00\right)$ (Fig. $\left.2 \mathrm{G}\right)$. The increase in the number of Acaridae reduced that of Histiostoma sp. $\left(\mathrm{R}^{2}=0.16\right.$, $P<0.04$ ) (Fig. $2 \mathrm{H}$ ).

\section{Parasitism and predation}

The numbers of Eurytomasp. $\left(\mathrm{R}^{2}=0.48, P<0.00\right)$ (Fig. $\left.3 \mathrm{~A}\right)$ and theirs groups of globoid galls $\left(\mathrm{R}^{2}=0.15, P<0.01\right)$ (Fig. $3 \mathrm{~B}$ ) correlated negatively with that of Sycophilasp. on C. brasilienseleaves. Higher $Z$. armillatus and Ablerus magistrettiBlanchard(Hymenoptera: Aphelinidae) numbers reduced those of groups of Eurytoma sp. globoid galls $\left(\mathrm{R}^{2}=0.21, P<0.01\right)$ (Fig. $3 \mathrm{C}$ ) and theirs lengths $\left(\mathrm{R}^{2}=0.18, P<0.01\right.$ ) (Fig. $3 \mathrm{D}$ ), respectively. The number of Histiostoma sp. was negatively correlated with that of Agistemus sp. (Stigmaeidae) $\left(\mathrm{R}^{2}=0.63, P<0.00\right)$ (Fig. $3 \mathrm{E}$ ). On the other hand, the higher percentage of leaflets with Eurytomasp. globoid galls increased the number of Sycophila sp. $\left(\mathrm{R}^{2}=0.14, P<0.01\right)$ (Fig. $\left.3 \mathrm{~F}\right)$. High numbers of Sycophila sp. $\left(\mathrm{R}^{2}=0.16, P<0.01\right)$ (Fig. $\left.3 \mathrm{G}\right)$ and Quadrastichus sp. $\left(\mathrm{R}^{2}=0.11, P<0.03\right)$ (Fig. $3 \mathrm{H}$ ) increased that of Holopothripssp. (Thysanoptera: Phlaeothripidae). The numbers of Eurytoma sp. adults $\left(\mathrm{R}^{2}=0.11, P<0.03\right)$ (Fig. $4 \mathrm{~A}$ ) and of their globoid galls $\left(\mathrm{R}^{2}=0.18, P<0.02\right)$ (Fig. $\left.4 \mathrm{~B}\right)$, and Sycophila sp. $\left(\mathrm{R}^{2}=0.17\right.$, $P<0.01$ ) (Fig. 4 C), on $C$. brasiliense leaves, were negatively correlated with those of spiders. The greater number of the latter organism was positively correlated with those of Eurytoma sp. groups of globoid gall $\left(\mathrm{R}^{2}=0.15, P<0.01\right)$ (Fig. $\left.4 \mathrm{D}\right)$, Chrysoperla sp. (Neuroptera: Chrysopidae) $\left(\mathrm{R}^{2}=0.33, P<0.00\right)$ (Fig. $\left.4 \mathrm{E}\right)$, and $A$. gossypii $\left(\mathrm{R}^{2}=0.31, P<0.00\right)$ (Fig. $\left.4 \mathrm{~F}\right)$. The numbers of Chrysoperla sp. were positively correlated with those of A. gossypii $\left(\mathrm{R}^{2}=0.82, P<0.00\right)$ (Fig. $4 \mathrm{G}$ ).

\section{Discussion}

\section{Relative frequency}

The high relative frequency of Eurytomasp., a unique galling insect, on C. brasilienseleaves indicates the great potential of this insect to become a pest in commercial $C$. brasiliense plantations causing premature abscission of leaves from this plant (Leite et al., 2020). The specific relative frequency of Tetranychus sp.1 (phytophagous mite) and A. gossypii (phytophagous Hemiptera) was also the highest of their groups and both are pests of $C$. brasiliense (Leite et al., 2006b, 2021). The number of individuals of Sycophila sp. (Eurytoma sp. parasitoid) and the predator $Z$. armillatus were the highest in their groups and, for this reason, may be important natural enemies of this galling insect (Leite et al., 2017). 

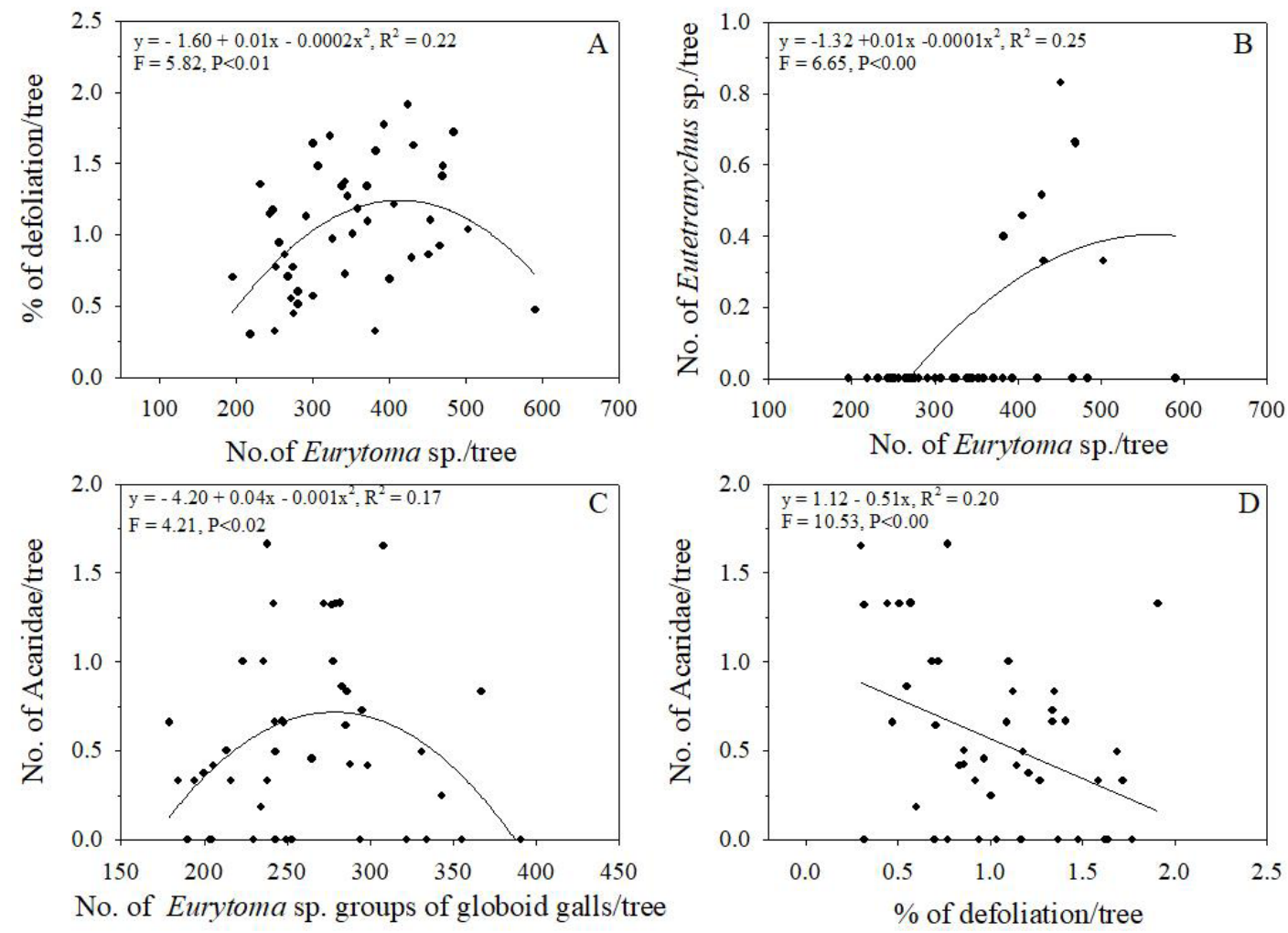

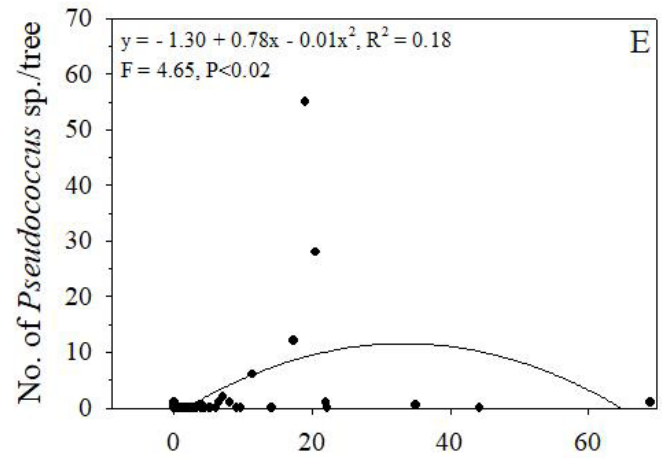

No. of Aphis gossypii/tree

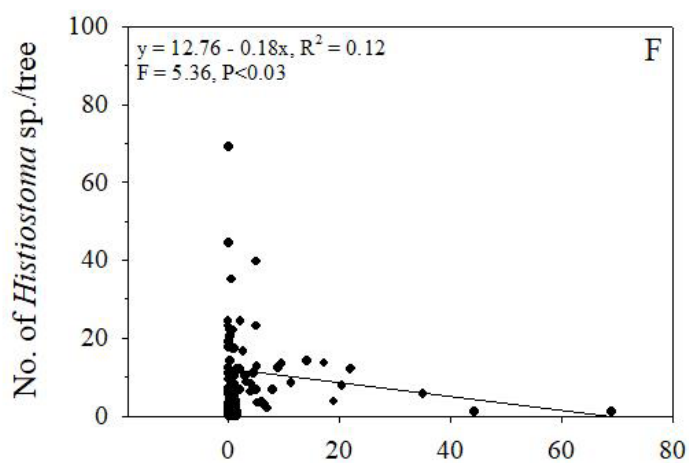

No. of Aphis gossypii/tree

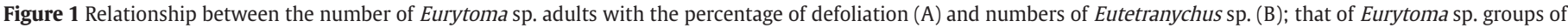

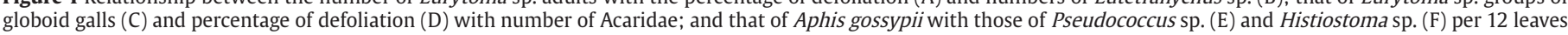
on Caryocar brasiliense trees in three years. Montes Claros, Minas Gerais State, Brazil. The symbols represent the averages. $\mathrm{N}=45$.

\section{Competition between herbivores}

The inverse correlation between the defoliation and the number of galling insects and defoliators (e.g., Eurytoma sp. x defoliation) and phytophagous mites (e.g., Eurytoma sp. x Eutetranychus sp.) was similar to that observed between sucking insects (e.g., A. gossypii x Pseudococcus sp.), phytophagous mites (e.g., Tetrachychus sp.1 x Tetrachychussp.2), and of A. gossypii with Histiostoma sp. on C. brasiliense trees. The relationship between galling insects and of other free-feeding herbivores may be a consequence of competition for food and space on C. brasiliense trees as observed with the high abundance of $A$. gossypii, Pseudococcussp. and Eurytoma sp. on leaves of seedlings and adult trees of $C$. brasiliense (Leite et al., 2006b, 2007). In addition, galling insect populations adapt locally to individual trees, that is, those that are of better quality (Egan and Ott, 2007). The lower number of coleopteran and lepidopteran defoliators on $C$. brasiliense leaves in the university campus than in the cerrado and pasture environments, probably, resulted from competition for food and space with galling insects and aphids, similarly for Eurytoma sp. with three other galling hymenopterans (Leite et al., 2012c, 2017). Moreover, ecosystem engineering, realized by organisms that modify the physical environment, can initiate cascades of trophic interactions that shape the structure of the community in no expected ways, and may have negative indirect effects on abundance and diversity in community components that do not interact directly with habitat modifications (Wetzel et al., 2016). The galling insects, that have limited mobility, can be attractive food sources for other herbivores. In this case, it is important for galling insects to develop efficient defense techniques (Yamazaki, 2016). One possibility, in the course of evolution, was to visually resemble caterpillars (Lepidoptera), reducing the herbivory of plant tissues by herbivores, including galls in these tissues (Yamazaki, 2016). This is due to other herbivores can avoid colonizing or consuming parts of the plant that appear to be occupied by other herbivores. In addition, galls that resemble caterpillars can attract natural enemies that will reduce the populations of real caterpillars, favoring galls (Yamazaki, 2016). Competition among predator mites for free space (Hammen et al., 2012; Strodl and Schausberger, 


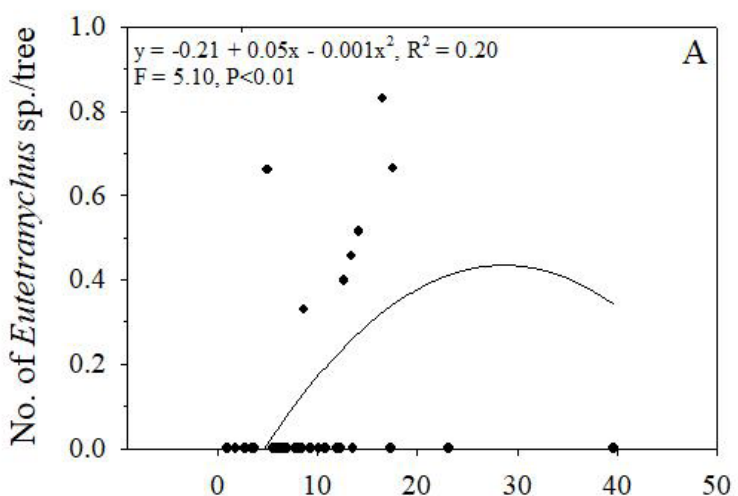

No. of Histiostoma sp./tree
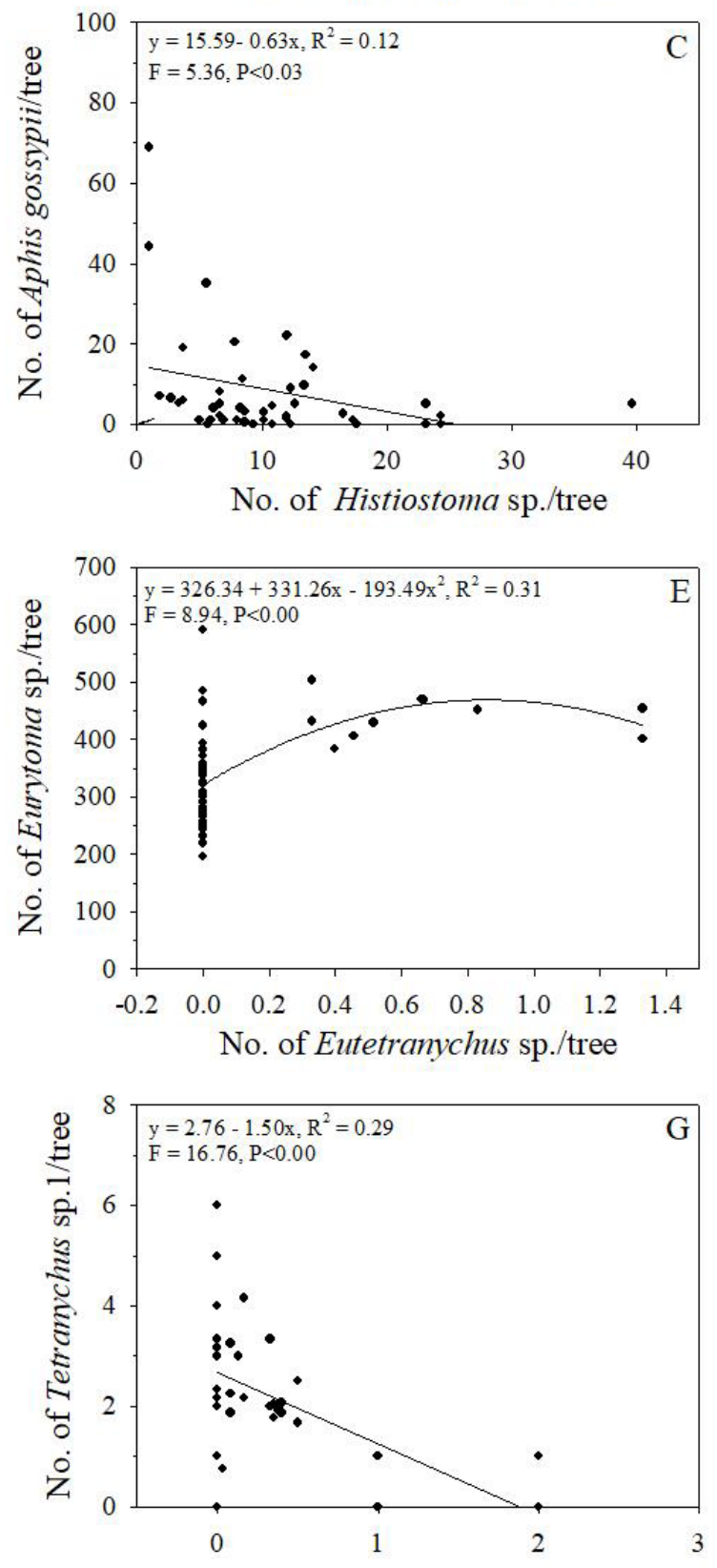

No. of Tetranychus sp.2/tree

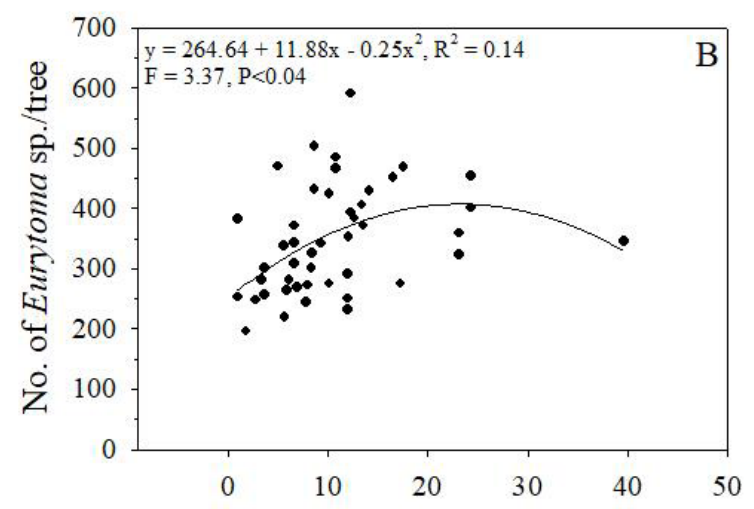

No. of Histiostoma sp./tree
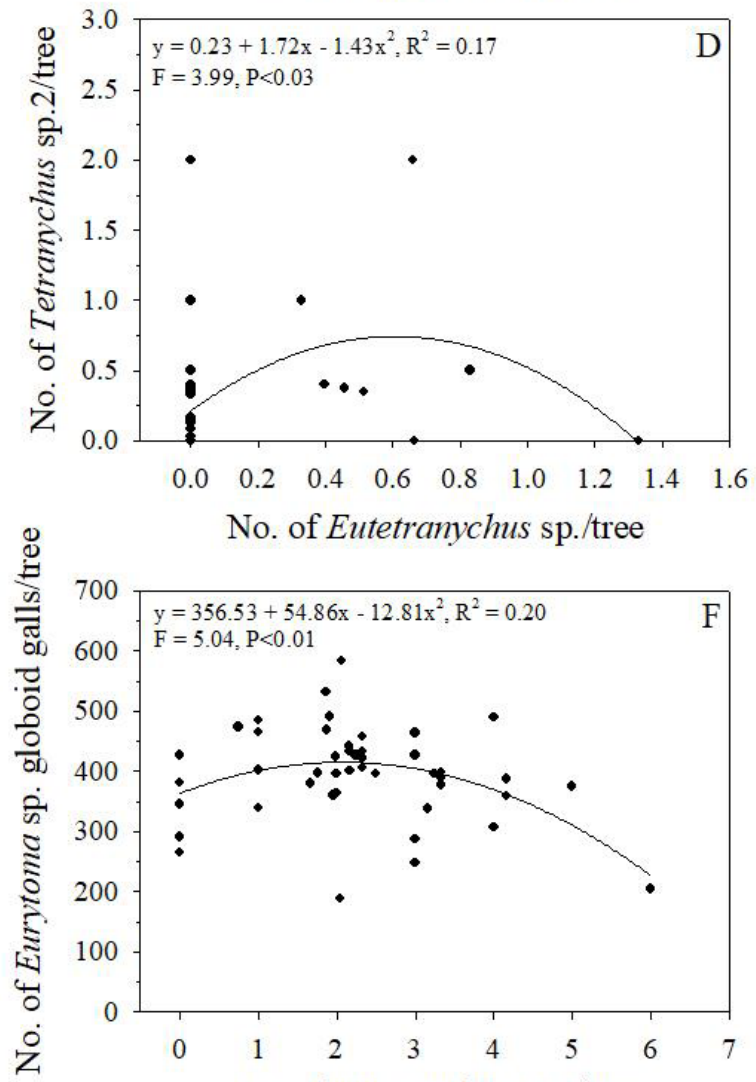

No. of Tetranychus sp.1/tree

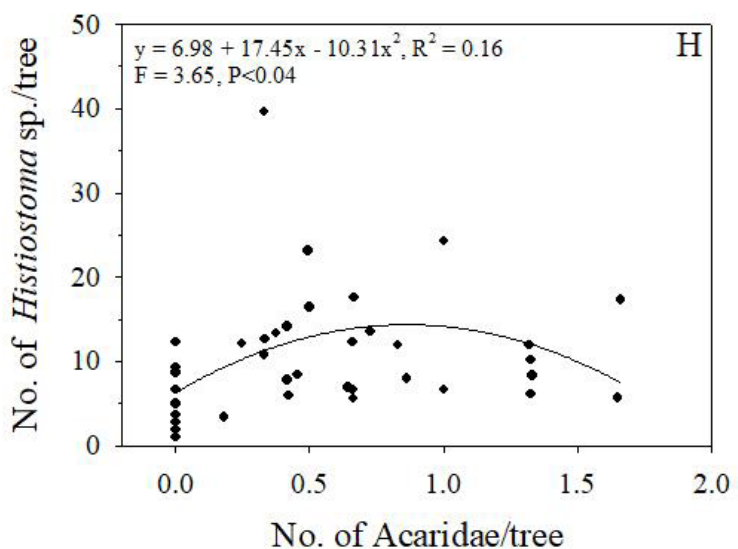

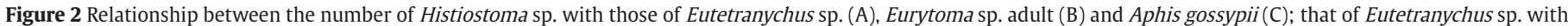

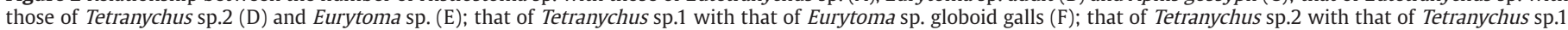

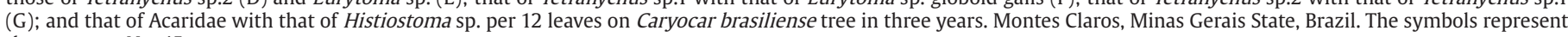
the averages. $\mathrm{N}=45$. 

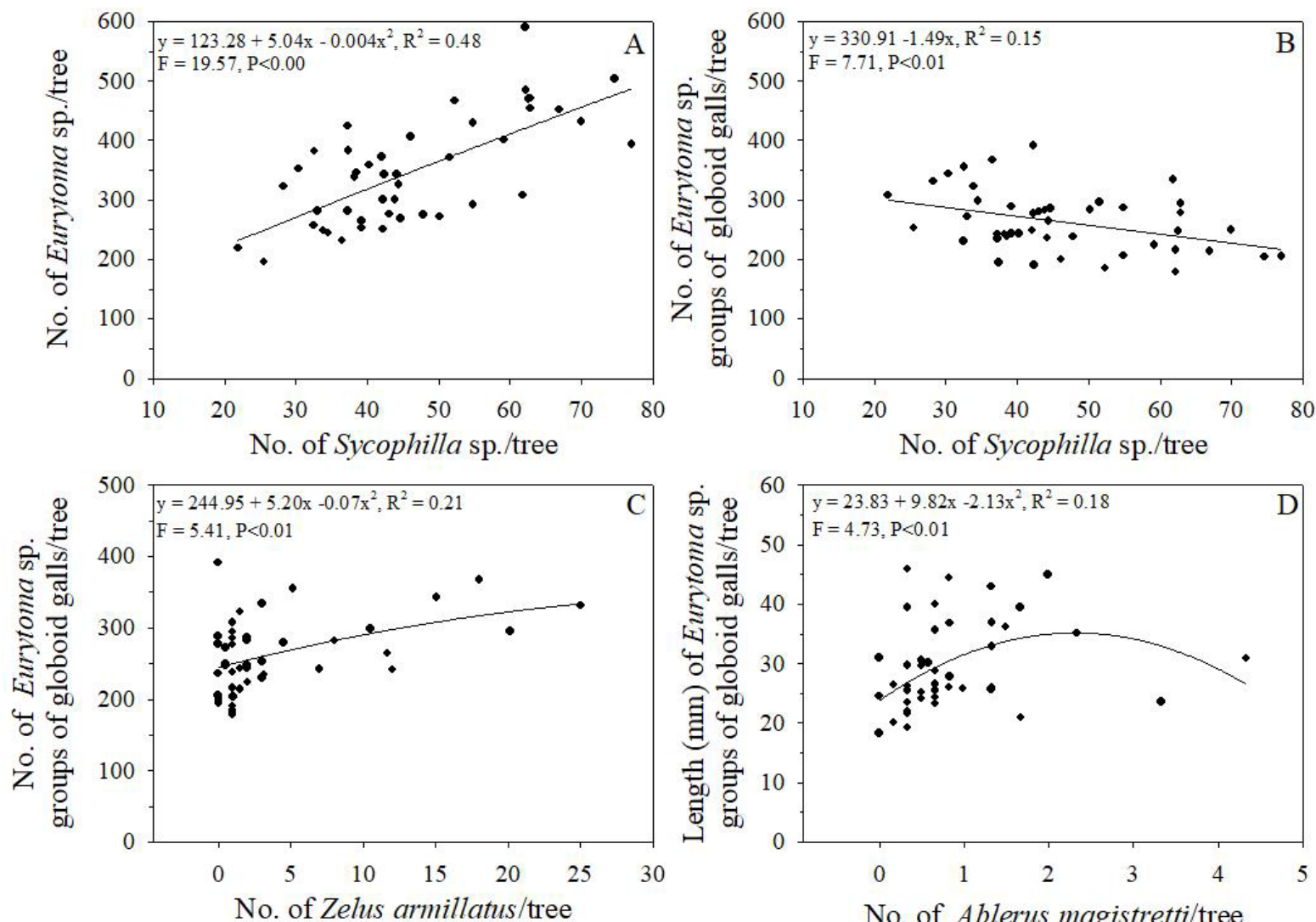

No. of Ablerus magistretti/tree
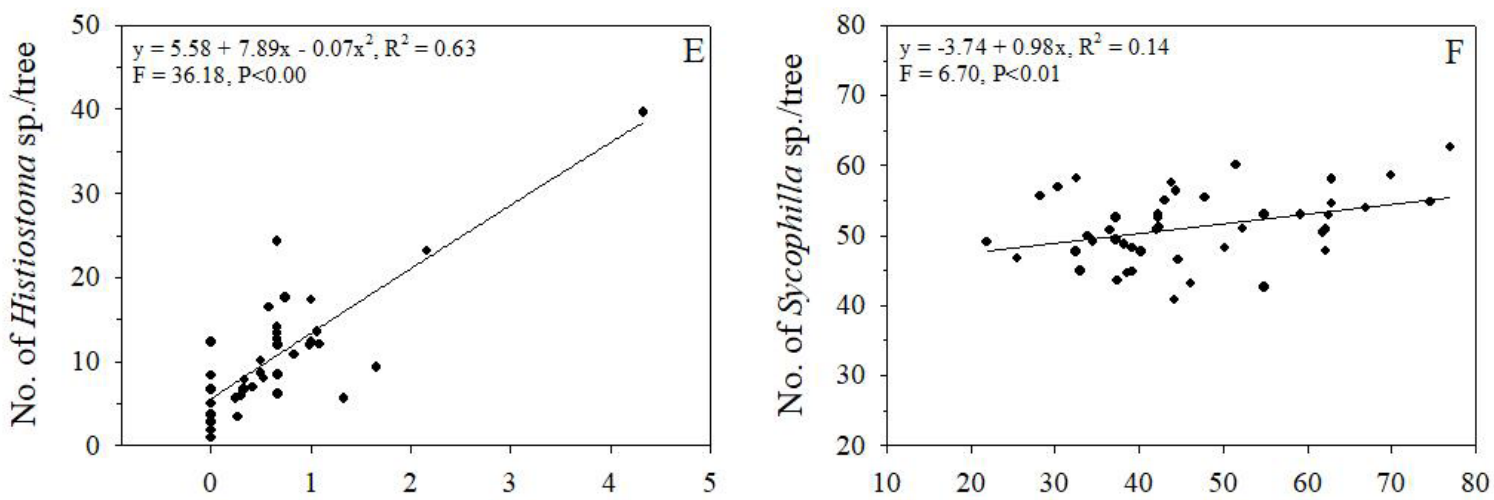

No. of Agistemus sp./tree
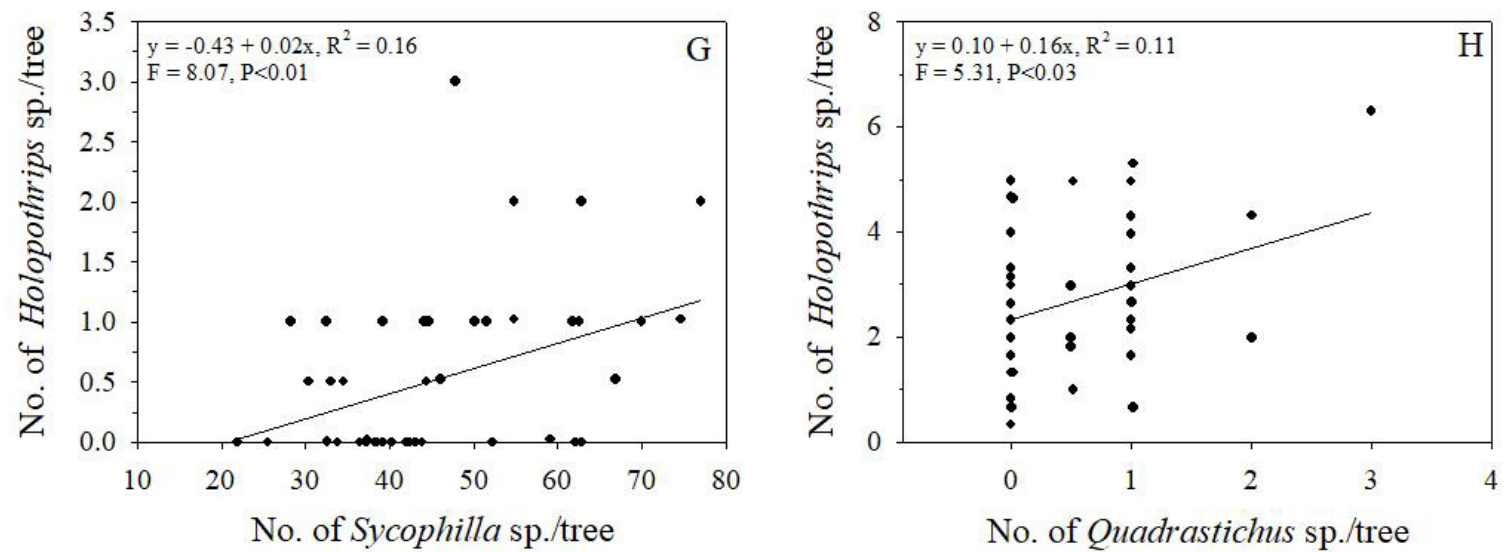

No. of Quadrastichus sp./tree

Figure 3 Relationship between the number of Sycophila sp. with those of Eurytoma sp. (A) and its globoid galls (B); that of Zelus armillatus with that of Eurytoma sp. groups of globoid galls (C); that of Ablerus magistretti with the length of Eurytoma sp. groups of globoid galls (D); number of Agistemus sp with that of Histiostoma sp. (E); percentage of leaflets with Eurytoma sp. globoid galls with the number of Sycophila sp. (F); that of Sycophila sp. with that of Holopothrips sp. (G); and that of Quadrastichus sp. with that of Holopothrips sp. (H) per 12 leaves on Caryocar brasiliense tree in three years. Montes Claros, Minas Gerais State, Brazil. The symbols represent the averages. $\mathrm{N}=45$. 

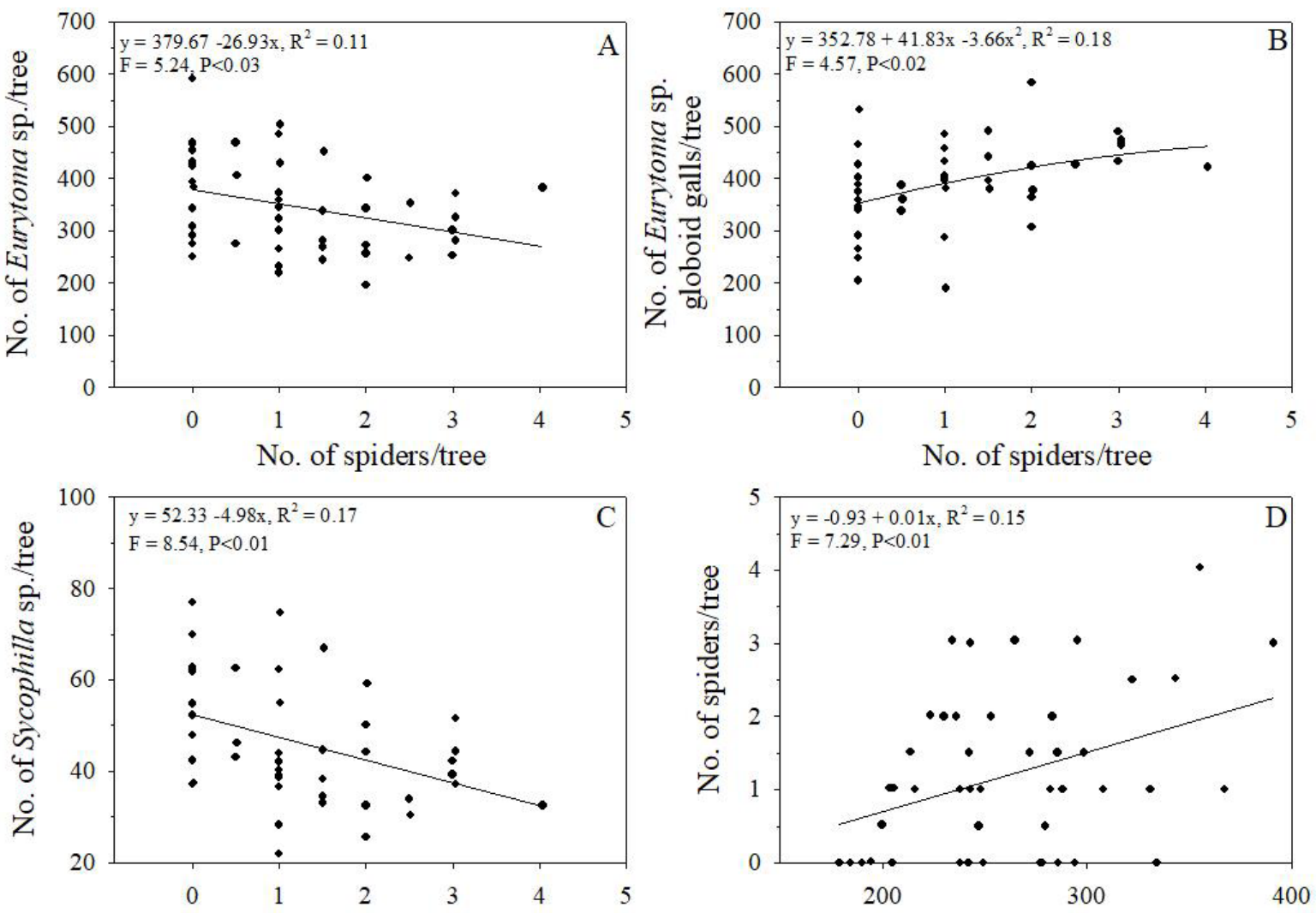

No. of spiders/tree
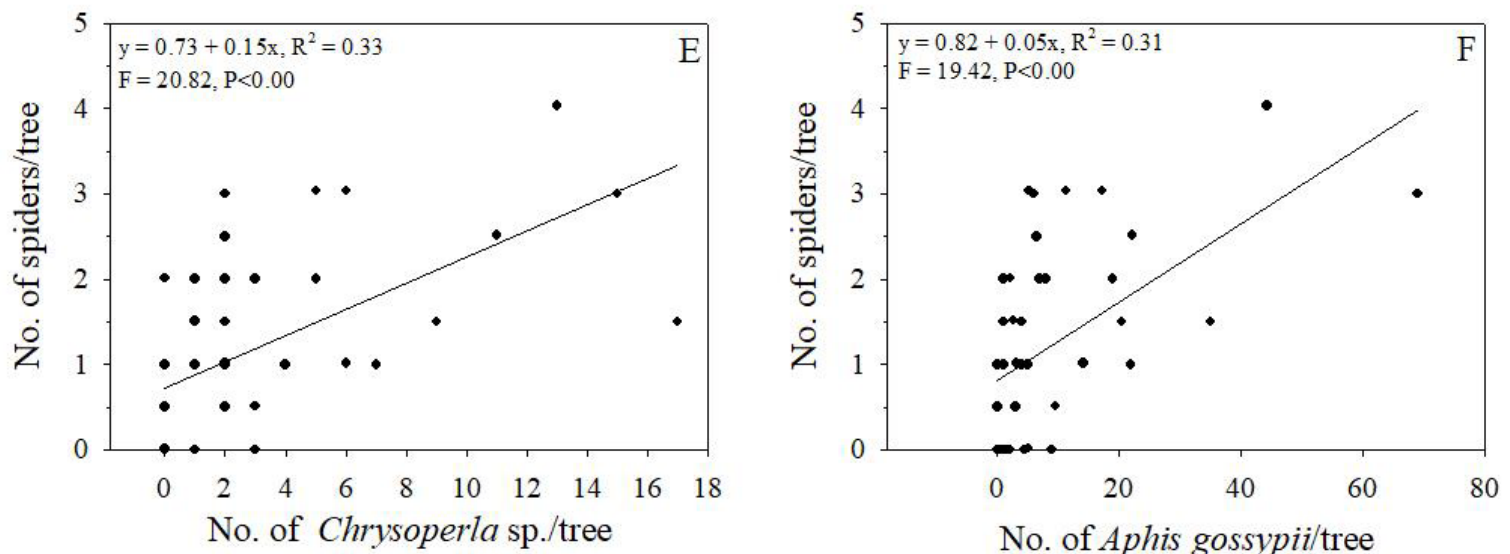

No. of Aphis gossypii/tree

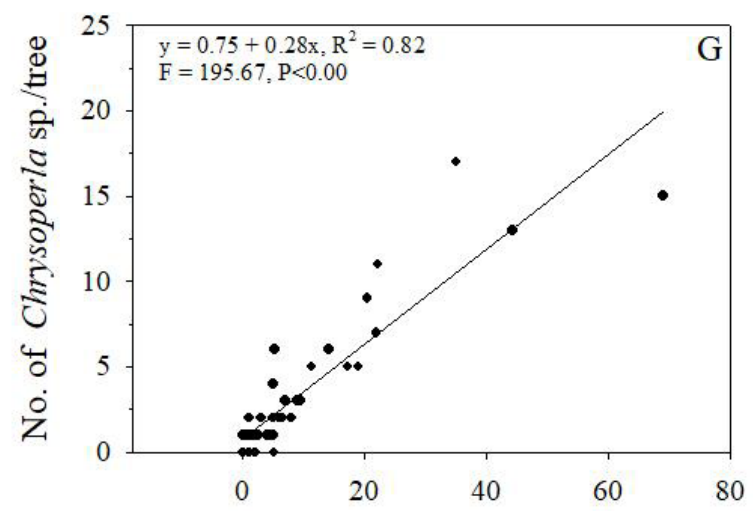

No. of Aphis gossypii/tree

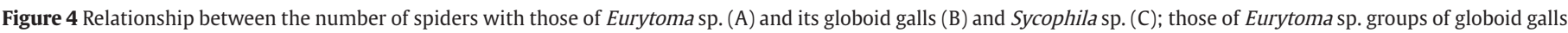

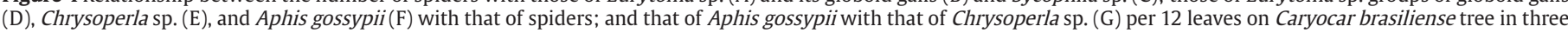
years. Montes Claros, Minas Gerais State, Brazil. The symbols represent the averages. $\mathrm{N}=45$. 
2012) and T. urticae females (Macke et al., 2012) have been reported. The importance of this last group in the tropics was confirmed by the competition with defoliators and gall-formers, aphids, leafhoppers, miners and mites (Morris et al., 2004). Phylogenetic proximity tends to favor the formation and maintenance of groups of mixed species (eussocial or gregarious), possibly due to similar scales in size, life parameters and communication between members (Boulay et al., 2019), but this can increase competition between species sharing similar ecological niches (Boulay et al., 2019). The balance between resource sharing and competition is important to understand species clusters occupying the same ecological niche with low food availability or few reproductive partners (Boulay et al., 2019). Arthropods use mixtures of chemical compounds, such as hydrocarbons, for communication, but interspecific competition can benefit one species at the expense of another (Boulay et al., 2019). Food webs are complex due to interactions between host plants, phytophagous insects, predators, parasitoids, and soil and climatic conditions (Gratton and Denno, 2003), especially in the Cerrado (Marquis et al., 2001; Gratton and Denno, 2003; Morris et al., 2004). The competition affects arthropod distribution on C. brasiliense plants confirming our initial hypothesis.

\section{Parasitism and predation}

Possible effect of predation on galling insects (e.g., Z. armillatus $\mathrm{x}$ Eurytoma sp. galls), phytophagous mites (e.g., Agistemussp. x Histiostoma sp.), sucking insects (e.g., Chrysoperla sp. x A. gossypii), predators (e.g., spiders x Chysoperla sp.) and parasitoids (e.g., Holopothrips sp. x Sycophila sp.), and parasitism (e.g., Sycophila sp. x Eurytoma sp.) on $C$. brasiliense trees were observed. The high number of the predator Z. armillatus and the parasitoids Sycophila sp. and A. magistretti determined the number of Eurytoma sp. and its galls. This shows the importance of these natural enemies in controlling this galling insect on C. brasiliense trees (Leite et al., 2007, 2009, 2012c). The correlations between indole butyric acid (phytohormone) and globoid galls and numbers of adult Eurytoma sp. and, consequently, its major parasitoid Sycophila sp. - following its host, on the $C$. brasiliense plants were positive (Leite et al., 2007) and galling insects may select plants with higher concentrations of the hormone indole butyric acid, which may play a role in gall induction (Leite et al., 2007). These observations highlight the importance of studies regarding plant hormones in gall formation and its indirect effect on parasitoids (Leite et al., 2007). The higher numbers of the predator $Z$. armillatus, Holopothrips sp., and spiders on $C$. brasiliense trees at the university campus may be due to the higher numbers of Eurytoma sp. galls on leaves of this plant in this area compared to those in the pastureland and in the Cerrado (Leite et al., 2012c). Zelus armillatus preyed on Eurytoma galls colonizing up to $70 \%$ of $C$. brasiliense leaf area (Leite et al., 2006b, 2007,2009 ) and these galls support a high diversity of natural enemies generating consequent mortality - top down effect - (Price et al., 2004; McGeoch and Price, 2005; Price, 2005). The higher number of green lacewings at the university campus may be due to the large number of A. gossypii individuals given the proximity of a legume production area (e.g., okra) (Leite et al., 2012c). The negative correlation between the predatory mite Agistemus sp. and the herbivore mite Histiostoma sp. on $C$. brasiliense leaves shows the importance of that natural enemy controlling phytophagous mites and the necessity of increasing floristic diversity to maintain or to increase its populations (Leite et al., 2008; Saber and Rasmy, 2010; Eichelberger et al., 2011).

The phytophagous arthropods Eurytoma sp. (galling insect), Tetranychus sp.1 (mite), and A. gossypii (sucking insect) show that these arthropods can become pests in commercial $C$. brasiliense plantations. These arthropod groups had important natural enemies including Agistemus sp. (mite predator), Chrysoperla sp. (aphid predator), Sycophila sp. (Eurytoma sp. parasitoid), and Z. armillatus (Eurytomasp. predator). The possible competition between the galling insect Eurytoma sp. with defoliators and the mite Eutetranychus sp., A. gossypii with Pseudococcus sp. (sucking insects), and Tetrachychus sp.1 with Tetrachychus sp. is, for the first time, an inter-specific relationship reported between species in $C$. brasiliense monoculture system (orchard). Results obtained during the three years indicate that possible competitive interactions between arthropods herbivorous, predator and parasitoid may reduce Eurytoma sp. numbers, a potential pest for $C$. brasiliense, and other herbivores and predators on this plant. The hypothesis that competition affects Eurytoma sp. distribution in C. brasiliense can be verified with studies of arthropod interactions on trees of this species (e.g., exclusion experiments).

\section{Acknowledgments}

We thank Dr. A.L. Matioli and Dr. E.A. Ueckermann (Acari); Dr. I.C. Nascimento and Dr. C. Matrangolo (Formicidae); Dr. V.C. Maia (Diptera); Dr. A.L.B.G. Peronti, Dr. C.R.S. Silva, Dr. L.B.N. Coelho, and Dr. P.S.F. Ferreira (Hemiptera); Dr. M.A.P. de Azevedo and Dr. O.H.H. Mielke (Hymenoptera); and Dr. R.C. Monteiro (Thysanoptera) for the identification of the specimens collected. We also thank "Conselho Nacional de Desenvolvimento Científico e Tecnológico" (CNPq), "Fundação de Amparo à Pesquisa do Estado de Minas Gerais (FAPEMIG) and "Secretaria de Ciência e Tecnologia do Estado de Minas Gerais". Dr. Phillip John Villani (University of Melbourne, Australia) revised and corrected the English language used in this manuscript.

\section{Funding}

"Conselho Nacional de Desenvolvimento Científico e Tecnológico" (CNPq: 305057/2018-9), "Fundação de Amparo à Pesquisa do Estado de Minas Gerais" (FAPEMIG: CAG - PPM-00080-17) and "Programa Cooperativo sobre Proteção Florestal (PROTEF) do Instituto de Pesquisas e Estudos Florestais (IPEF)".

\section{Conflicts of interest}

The authors declare no conflicts of interest.

\section{Author contribution statement}

The study was conceived and designed by GLDL, data were collected by RVSV with support from GLDL, data analysis and writing was performed by GLDL, PGL, GWF and JCZ. Figures, tables and manuscript preparation was done by MAS. All authors contributed to writing, revisions and approve the final version of the manuscript.

\section{References}

Alvares, C. A., Stape, J. L., Sentelhas, P. C., Gonçalves, J. L. M., Sparovek, G., 2013. Köppen's climate classification map for Brazil. Meteorol Z. 22, 711-728. https://doi.org/10.1127/0941-2948/2013/0507.

Barnes, A., Jochum, M., Mumme, S., Haneda, N. F., Farajallah, A., Widarto, T. H., Brose, U., 2014. Consequences of tropical land use for multitrophic biodiversity and ecosystem functioning. Nat. Commun. 5, 5351. https://doi.org/10.1038/ ncomms6351. 
Birkhofer, K., Smith, H. G., Weisser, W. W., Wolters, V., Gossner, M. M., 2015. Land-use effects on the functional distinctness of arthropod communities. Ecography 38, 889-900. https://doi.org/10.1111/ ecog.01141.

Boulay, J., Aubernon, C., Ruxton, G. D., Edouin, V. H., Deneubourg, J. L., Charabidze, D., 2019. Mixed-species aggregations in arthropods. Insect Sci. 26, 2-19. https://doi.org/10.1111/1744-7917.12502.

Bridgewater, S., Ratter, J. A., Felipe Ribeiro, J., 2004. Biogeographic patterns, $\beta$-diversity and dominance in the cerrado biome of Brazil. Biodivers. Conserv. 13, 2295-2317. https://doi.org/10.1023/ B:BIOC.0000047903.37608.4c.

Chailleux, A., Droui, A., Bearez, P., Desneux, N., 2017. Survival of a specialist natural enemy experiencing resource competition with an omnivorous predator when sharing the invasive prey Tuta absoluta. Ecol. Evol. 7, 8329-8337. https://doi.org/10.1002/ece3.3396.

Coelho, L. B. N., Leite, G. L. D., Da-Silva, E. R., 2014. A new species of Dikrella Oman, 1949 (Hemiptera: Cicadellidae: Typhlocybinae) found on Caryocar brasiliense Cambess. (Caryocaraceae) in Minas Gerais State, Brazil. Psyche (Stuttg.) 871605, https://doi. org/10.1155/2014/871605.

Colli, G. R., Vieira, C. R., Dianese, J. C., 2020. Biodiversity and conservation of the Cerrado: recent advances and old challenges. Biodivers. Conserv. 29, 1465-1475. https://doi.org/10.1007/s10531-020-01967-X.

Crutsinger, G. M., Reynolds, W. N., Classen, A. T., Sanders, N. J., 2008. Disparate effects of plant genotypic diversity on foliage and litter arthropod communities. Oecologia 158, 65-75. https://doi. org/10.1007/s00442-008-1130-y.

Da Silva, J. M. C., Bates, J. M., 2002. Biogeographic Patterns and Conservation in the South American Cerrado: a Tropical Savanna Hotspot: The Cerrado, which includes both forest and savanna habitats, is the second largest South American biome, and among the most threatened on the continent. Bioscience 52, 225-234. https://doi.org/10.1641/0006-3568(2002)052[0225:BPACIT]2.0.CO;2.

Egan, S. P., Ott, J. R., 2007. Host plant quality and local adaptation determine the distribution of a gall-forming herbivore. Ecology 88 , 2868-2879. Available in: https://www.jstor.org/stable/27651445 (accessed 30 June 2018).

Eichelberger, C. R., Johann, L., Majolo, F., Ferla, N. J., 2011. Mites fluctuation population on peach tree (Prunus persica (L.) Batsch) and in associated plants. Rev. Bras. Frutic. 33, 765-773. https://doi. org/10.1590/S0100-29452011005000102.

Espírito-Santo, M. M., Neves, F. S., Andrade-Neto, F. R., Fernandes, G. W., 2007. Plant architecture and meristem dynamics as the mechanisms determining the diversity gall-inducing insects. Oecologia 153 , 353-364. https://doi.org/10.1007/s00442-007-0737-8.

Giroldo, A. B., Scariot, A., 2015. Land use and management affects the demography and conservation of an intensively harvested Cerrado fruit tree species. Biol. Conserv. 191, 150-158. https://doi. org/10.1016/j.biocon.2015.06.020.

Gonçalves, T. A. P., Nisgoski, S., Oliveira, J. S., Marcati, C. R., Ballarin, A. W., Muñiz, G. I. B., 2016. A contribution to the identification of charcoal origin in Brazil II - Macroscopic characterization of Cerrado species. An. Acad. Bras. Cienc. 88, 1045-1054. https://doi. org/10.1590/0001-3765201620150322.

Gratton, C., Denno, R. F., 2003. Seasonal shift from bottom-up to topdown impact in phytophagous insect populations. Oecology. 134, 487-495. https://doi.org/10.1007/s00442-002-1137-8.

Hammen, T., Montserrat, M., Sabelis, M. W., Roos, A. M., Janssen, A., 2012. Whether ideal free or not, predatory mites distribute so as to maximize reproduction. Oecologia 169, 95-104. https://doi. org/10.1007/s00442-011-2190-y.
Khouri, J., Resck, I. S., Poças-Fonseca, M., Sousa, T. M. M., Pereira, L. O., Oliveira, A. B. B., Grisolia, C. K., 2007. Anticlastogenic potential and antioxidant effects of an aqueous extract of pulp from the pequi tree (Caryocar brasiliense Camb). Genet. Mol. Biol. 30, 442-448. https://doi.org/10.1590/S1415-47572007000300024.

Koricheva, J., Hayes, D., 2018. The relative importance of plant intraspecific diversity in structuring arthropod communities: a meta-analysis. Funct. Ecol. 32, 1704-1717. https://doi.org/10.1111/1365-2435.13062.

Laste, K. C. D., Durigan, G., Andersen, A. N., 2019. Biodiversity responses to land-use and restoration in a global biodiversity hotspot: ant communities in Brazilian Cerrado. Austral Ecol. 44, 313-326. https:// doi.org/10.1111/aec.12676.

Leite, G. L. D., Picanço, M., Zanuncio, J. C., Marquini, F., 2003. Factors affecting mite herbivory on eggplants in Brazil. Exp. Appl. Acarol. 31, 243-252. https://doi.org/10.1023/B:APPA.0000010379.05878.2c.

Leite, G. L. D., Veloso, R. V. S., Zanuncio, J. C., Fernandes, L. A., Almeida, C. I. M., 2006a. Phenology of Caryocar brasiliense in the Brazilian Cerrado Region. For. Ecol. Manage. 236, 286-294. https://doi. org/10.1016/j.foreco.2006.09.013.

Leite, G. L. D., Veloso, R. V. S., Redoan, A. C. M., Lopes, P. S. N., Machado, M. M. L., 2006b. Arthropods associated to "piquizeiro" tree seedlings. Arq. Inst. Biol. (Sao Paulo) 73, 365-370.

Leite, G. L. D., Veloso, R. V. S., Castro, A. C. R., Lopes, P. S. N., Fernandes, G. W., 2007. Effect of AIB on quality and phytosanity of Caryocar brasiliense Camb. (Caryocaraceae) air layering. Rev. Arvore 31, 315-320. https://doi.org/10.1590/ S0100-67622007000200014.

Leite, G. L. D., Pimenta, M., Fernandes, P. L., Veloso, R. V. S., Martins, E. R., 2008. Fatores que afetam artrópodes associados a cinco acessos de ginseng-brasileiro (Pfaffia glomerata) em Montes Claros, Estado de Minas Gerais. Acta Sci. Agron. 30, 7-11. https://doi.org/10.4025/ actasciagron.v30i1.1110.

Leite, G. L. D., Veloso, R. V. S., Silva, F. W. S., Guanabens, R. E. M., Fernandes, G. W., 2009. Within tree distribution of a gall-inducing Eurytoma (Hymenoptera, Eurytomidae) on Caryocar brasiliense (Caryocaraceae). Rev. Bras. Entomol. 53, 643-648. https://doi. org/10.1590/S0085-56262009000400015.

Leite, G. L. D., Veloso, R. V. S., Zanuncio, J. C., Alves, S. M., Amorim, C. A. D., Souza, O. F. F., 2011. Factors affecting Constrictotermes cyphergaster (Isoptera: Termitidae) nesting on Caryocar brasiliense trees in the Brazilian savanna. Sociobiology 57, 165-180.

Leite, G. L. D., Veloso, R. V. S., Zanuncio, J. C., Almeida, C. I. M., Ferreira, P. S. F., Fernandes, G. W., Soares, M. A., 2012a. Habitat complexity and Caryocar brasiliense herbivores (Insecta; Arachnida; Araneae). Fla. Entomol. 95, 819-830. https://doi.org/10.1653/024.095.0402.

Leite, G. L. D., Veloso, R. V. S., Zanuncio, J. C., Fernandes, G. W., Almeida, C. I. M., Ferreira, P. S. F., Lazo, J. A., Serrão, J. E., 2012b. Seasonal abundance of hemipterans on Caryocar brasiliense (Malpighiales: Caryocaraceae) trees in the Cerrado. Fla. Entomol. 95, 862-872. https://doi.org/10.1653/024.095.0407.

Leite, G. L. D., Veloso, R. V. S., Zanuncio, J. C., Almeida, C. I. M., Ferreira, P. S. F., Serrão, J. E., Ramalho, F. S., 2012c. Seasonal damage caused by herbivorous insects on Caryocar brasiliense (Caryocaraceae) trees in the Brazilian savanna. Rev. Colomb. Entomol. 38, 35-40.

Leite, G. L. D., Nascimento, A. F., Alves, S. M., Lopes, P. S. N., Sales, N. L. P., Zanuncio, J. C., 2012d. The mortality of Caryocar brasiliense in northern Minas Gerais State, Brazil. Acta Sci. Agron. 34, 131-137. https://doi.org/10.4025/actasciagron.v34i2.13120.

Leite, G. L. D., 2014. Galling insects on Caryocar brasiliense Camb. (Caryocaraceae). In: Fernandes G.W., Santos J.C. Neotropical Insect Galls (Eds.), Springer-Verlag, USA, pp. 179-192.

Leite, G. L. D., Veloso, R. V. S., Zanuncio, J. C., Alonso, J., Ferreira, P. S. F., Almeida, C. I. M., Fernandes, G. W., Serrão, J. E., 2016. Diversity 
of Hemiptera (Arthropoda: Insecta) and their natural enemies on Caryocar brasiliense (Malpighiales: Caryocaraceae) trees in the Brazilian Cerrado. Fla. Entomol. 99, 239-247. https://doi. org/10.1653/024.099.0213.

Leite, G. L. D., Veloso, R. V. S., Zanuncio, J. C., Azevedo, A. M., Silva, J. L., Wilcken, C. F., Soares, M. A., 2017. Architectural diversity and galling insects on Caryocar brasiliense trees. Sci Rep-Uk. 7, 1-7. https:// doi.org/10.1038/s41598-017-16954-6.

Leite, G. L. D., Veloso, R. V. S., Soares, M. A., Fernandes, G. W., Zanuncio, J. C., Oliveira, N. A., Santos Junior, V. C., 2020. Does environmental diversity affect hymenopteran galling insects and their natural enemies on Caryocar brasiliense trees (Caryocaraceae)? Rev. Colomb. Entomol. 46, e8546. https://doi.org/10.25100/socolen.v46i1.8546.

Leite, G. L. D., Veloso, R. V. S., Matioli, A. L., Feres, C. I. M. A., Soares, M. A., Alves, P. G. L., Pereira, A. I. A., Zanuncio, J. C., 2021. Habitat complexity and mite population on Caryocar brasiliense trees. Acta Sci. Agron. 43, e50164. https://doi.org/10.4025/actasciagron. v43i1.50164.

Liu, Y. H., Xu, C., Li, Q. L., Zhou, A., 2020. Interference competition for mutualism between ant species mediates ant-mealybug associations. Insects 11, 91. https://doi.org/10.3390/insects11020091.

Macke, E., Magalhaes, S., Hong Do, T. K., Frantz, A., Facon, B., Olivieri, I., 2012. Mating modifies female life history in a haplodiploid spider mite. Am. Nat. 179, 147-162. https://doi.org/10.1086/665002.

Marquis, R. J., Diniz, I. R., Morais, H. C., 2001. Patterns and correlates of the interspecific variation in foliar insect herbivory and pathogen attack in Brazilian cerrado. J. Trop. Ecol. 17, 127-148. https://doi. org/10.1017/S0266467401001080.

McGeoch, M. A., Price, P. W., 2005. Scale-dependent mechanisms in the population dynamics of an insect herbivore. Oecologia 144, 278-288. https://doi.org/10.1007/s00442-005-0073-9.

Morris, R. J., Lewis, O. T., Godfray, H. C. J., 2004. Experimental evidence for apparent competition in a tropical forest food web. Nature 428 , 310-313. https://doi.org/10.1038/nature02394.

Oliveira, P. S., Marquis, R. J., 2002. The Cerrados of Brazil. Ecology and Natural History of a Neotropical Savanna, Columbia University Press, New York.

Pinheiro, M. H. O., Monteiro, R., 2010. Contribution to the discussions on the origin of the cerrado biome: brazilian savanna. Braz. J. Biol. 70, 95-102. https://doi.org/10.1590/S1519-69842010000100013.

Price, P. W., 2005. Adaptive radiation of gall-inducing insects. Basic Appl. Ecol. 6, 413-421. https://doi.org/10.1111/j.1558-5646.2007.00069.x.

Price, P. W., Ohgushi, T., Roininen, H., Ishihara, M., Craig, T. P., Tahvanainen, J., Ferrier, S. M., 2004. Release of phylogenetic constraints through low resource heterogeneity: the case of gall-inducing sawflies. Ecol. Entomol. 29, 467-481. https://doi.org/10.1111/j.03076946.2004.00626.x.

Roitman, I., Bustamante, M. M. C., Haidar, R. F., Shimbo, J. Z., Abdala, G. C., Eiten, G., Fagg, C. W., Felfili, M. C., Felfili, J. M., Jacobson, T. K. B., Lindoso, G. S., Keller, M., Lenza, E., Miranda, S. C., Pinto, J. R. R., Rodrigues, A. A., Delitti, W. B. C., Roitman, P., Sampaio, J. M., 2018. Optimizing biomass estimates of savanna woodland at different spatial scales in the Brazilian Cerrado: re-evaluating allometric equations and environmental influences. PLoS One 13, e0196742. https://doi.org/10.1371/journal.pone.0196742.

Saber, A. S., Rasmy, A. H., 2010. Influence of plant leaf surface on the development, reproduction and life table parameters of the predacious mite, Agistemus exsertus Gonzalez (Acari: stigmaeidae). Crop Prot. 29, 789-792. https://doi.org/10.1016/j.cropro.2010.04.001.

Sanders, D., Thébault, E., Kehoe, R., van Veen, F.J. F., 2018. Trophic redundancy reduces vulnerability to extinction cascades. Proc. Natl. Acad. Sci. USA 115, 2419-2424. https://doi.org/10.1073/pnas.1716825115.
Sano, E. E., Rosa, R., Brito, J. L. S., Ferreira, L. G., 2010. Land cover mapping of the tropical savanna region in Brazil. Environ. Monit. Assess. 166, 113-124. https://doi.org/10.1007/s10661-009-0988-4.

Santos, L. M., Lenza, E., dos Santos, J. O., Marimon, B. S., Eisenlohr, P. V., Junior, B. H. M., Feldpausch, T. R., 2015. Diversity, floristic composition, and structure of the woody vegetation of the Cerrado in the Cerrado-Amazon transition zone in Mato Grosso, Brazil. Braz. J. Bot. 38, 877-887. https://doi.org/10.1007/s40415-015-0186-2.

Santos, P. H. R., Giordani, S. C. O., Soares, B. C., Silva, F. H. L., Esteves, E. A., Cunha Fernandes, J. S. C., 2018. Genetic divergence in populations of Caryocar brasiliense Camb. from the physical characteristics of the fruits. Rev. Arvore 42, e420116. https://doi.org/10.1590/180690882018000100016.

São-Mateus, W. M. B., Simon, M. F., de Queiroz, L. P., Jardim, J. G., Cardoso, D. B. O. S., 2019. Two new species of Harpalyce (Leguminosae, Papilionoideae) from the Cerrado hotspot of biodiversity in Brazil. Kew Bull. 74, 61. https://doi.org/10.1007/s12225-019-9845-y.

Schumann, K., Wittig, R., Thiombiano, A., Becker, U., Hahn, K., 2010. Impact of land-use type and harvesting on population structure of a non-timber forest product providing tree in a semi-arid savanna, West Africa. Biol. Conserv. 144, 2369-2376. https://doi.org/10.1016/j. biocon.2011.06.018.

Segall, S. D., Artz, W. E., Raslan, D. S., Ferraz, V. P., Takahashi, J. A., 2005. Triacylglycerol analysis of pequi (Caryocar brasiliensis Camb.) oil by electrospray and tandem mass spectrometry. J. Sci. Food Agric. 86, 445-452. https://doi.org/10.1002/ jsfa.2349.

Silva, J. L., Leite, G. L. D., Tavares, W. S., Silva, F. W. S., Sampaio, R. A., Azevedo, A. M., Serrão, J. E., Zanuncio, J. C., 2020. Diversity of arthropods on Acacia mangium (Fabaceae) and production of this plant with dehydrated sewage sludge in degraded area. R. Soc. Open Sci. 7, 191196. https://doi.org/10.1098/rsos.191196.

Sistema para Análises Estatísticas - SAEG, 2007. Sistema para Análises Estatísticas - SAEG Versão 9.1. Available in: http://arquivo.ufv.br/ saeg/ (accessed 30 June 2018).

Souza, V. C., de Paula-Souza, J., 2016. Buchnera tacianae(Orobanchaceae), a new species from the Brazilian cerrado. Kew Bull. 71, 43. https:// doi.org/10.1007/s12225-016-9655-4.

Strodl, M. A., Schausberger, P., 2012. Social familiarity modulates group living and foraging behaviour of juvenile predatory mites. Naturwissenschaften 99, 303-311. https://doi.org/10.1007/s00114012-0903-7.

Supriya, K., Price, T. D., Moreau, C. S., 2020. Competition with insectivorous ants as a contributor to low songbird diversity at low elevations in the eastern Himalaya. Ecol. Evol. 10, 4280-4290. https://doi. org/10.1002/ece3.6196.

Symes, W. S., Edwards, D. P., Miettinen, J., Rheindt, F. E., Carrasco, L. R., 2018. Combined impacts of deforestation and wildlife trade on tropical biodiversity are severely underestimated. Nat. Commun. 9, 4052. https://doi.org/10.1038/s41467-018-06579-2.

Tredennick, A. T., de Mazancourt, C., Loreau, M., Adler, P. B., 2017. Environmental responses, not species interactions, determine synchrony of dominant species in semiarid grasslands. Ecology 98, 971-981. https://doi.org/10.1002/ecy.1757.

Ulyshen, M. D., 2011. Arthropod vertical stratification in temperate deciduous forests: implications for conservation-oriented management. For. Ecol. Manage. 261, 1479-1489. https://doi. org/10.1016/j.foreco.2011.01.033.

Vieira Junior, W. G., de Moura, J. B., de Souza, R. F., Braga, A., Matos, D., Brito, G., Dos Santos, J. M., Moreira, R. M., Dutra, E., Silva, S., 2020. Seasonal variation in mycorrhizal community of different Cerrado phytophysiomies. Front. Microbiol. 11, 576764. https:// doi.org/10.3389/fmicb.2020.576764. 
Wetzel, W. C., Screen, R. M., Li, I., McKenzie, J., Phillips, K. A., Cruz, M., Zhang, W., Greene, A., Lee, E., Singh, N., Tran, C., Yang, L. H., 2016. Ecosystem engineering by a gall-forming wasp indirectly suppresses diversity and density of herbivores on oak trees. Ecology 97, 427-438. https://doi.org/10.1890/15-1347.1.

Yamazaki, K., 2016. Caterpillar mimicry by plant galls as a visual defense against herbivores. J. Theor. Biol. 404, 10-14. https://doi. org/10.1016/j.jtbi.2016.05.028.
Zardo, R. N., Henriques, R. P. B., 2011. Growth and fruit production of the tree Caryocar brasiliense in the Cerrado of central Brazil. Agrofor. Syst. 82, 15-23. https://doi.org/10.1007/s10457-0119380-9.

Zvereva, E. L., Lanta, V., Kozlov, M. V., 2010. Effects of sap-feeding insect herbivores on growth and reproduction of woody plants: a metaanalysis of experimental studies. Oecologia 163, 949-960. https:// doi.org/10.1007/s00442-010-1633-1. 